\title{
Roma Hukukunda Vasiyetname Şekilleri
}

\author{
Forms Of Testament In Roman Law
}

Sevgi Kayak ${ }^{*}$ iD

\section{öz}

$\mathrm{Bu}$ çalışmanın amacı Roma Hukukunda vasiyetname şekillerini genel bir biçimde açıklamaktır. Vasiyetname Roma Hukukunun en önemli hukuki işlemlerinden biridir. Roma Hukukunda vasiyetname kamu hukuku alanında yer alır ve kamusal bir tasarruftur. Bu sebeple Roma Hukukunda vasiyetname şekle bağlıdır ve vasiyetname şekilleri törensel nitelik taşır. Ancak bu zor ve zahmetli şekiller nedeniyle Roma Hukukunda vasiyetname yapmak zordur ve bu şekiller zamanla pratik ihtiyaçlara göre basitleştirilmiştir. Roma Hukukunda başlıca vasiyetname türleri; testamentum calatis comitiis, testamentum in procinctu, testamentum per aes et libram, testamentum per scripturam, testamentum per nuncupationem'dir.

Anahtar Kelimeler: Roma Hukuku, Vasiyetname, Vasiyetname Şekilleri, Yazılı Şekil, Sözlü Şekil

\section{ABSTRACT}

The aim of this study is to explain the testament forms in general. The testament is one of the most important acts legal of Roman law. In Roman law, testament takes place in the field of public law and the testament is a public law act. Therefore, in Roman Law, the testament depends on the form and these forms have a ceremonial character. It is difficult to make a testament in Roman Law because of these difficult and laborious forms. These forms have been simplified over time to practical needs. Testamentum calatis comitiis, testamentum in procinctu, testamentum per aes et libram, testamentum per scripturam, testamentum per nuncupationem are the essential forms of testament in Roman Law.

Keywords: Roman Law, Testament, Forms of testament, Written Form, Verbal Form

\section{Roma Hukukunda Vasiyetname Kavramı}

Roma Hukuku kaynaklarında vasiyetnamenin tanımına biri Ulpianus tarafından Regulae ${ }^{1}$ da, diğeri Modestinus tarafından Digesta'da olmak üzere iki yerde rastliyoruz ${ }^{2}$. Regulae'da vasiyetname, “ölümümüzden sonra geçerli olması için, irademizin şeklen tespit edilmiş bir ifadesidir (testamentum est mentis nostrae iusta contestatio, in id sollemniter facta, ut post mortem nostram valeat)" biçiminde tarif edilmektedir3. Digesta’da ise vasiyetname, “ölümümüzden sonra gerçekleşmesini istediğimiz irademizin hukuksal şekildeki ifadesidir (testamentum est voluntatis nostrae iusta sententia de

* $\quad$ Doç. Dr., İstanbul Üniversitesi Hukuk Fakültesi Roma Hukuku Anabilim Dalı

1 Regulae; hukukun temel ilkelerini kısa ve veciz cümleler halinde bir araya getiren klasik bir eser tipidir. Neratius, Gaius, Pomponius, Saevola, Ulpianus, Paulus, Marcianus ve Modestinus gibi hukukçuların bu tipte eserleri olduğu bilinmektedir (Umur Z., Roma Hukuku Lügatı, İstanbul, İstanbul Üniversitesi Yayınları, 1983, s. 181).

2 Küçükgüngör E., Roma Hukukunda Vasiyet (Testamentum), Ankara, Yetkin Yayınları, 2007, s. 99.

3 Ulp. Reg., 20. 1, (çeviri için bkz. Di Marzo, S., Roma Hukuku, Beşinci Tab’ndan Çev. Ziya Umur, 2. Baskı, İstanbul, İstanbul Üniversitesi Yayınları, 1959, s. 512).

Sorumlu Yazar/Correspondence Author: Sevgi Kayak

E-posta/E-mail: sevgikayak@istanbul.edu.tr 
eo, quod quis post mortem suam fieri velit)" olarak tanımlanmaktadır ${ }^{4}$. Her iki tanım birlikte değerlendirildiğinde Roma Hukukunda vasiyetnamenin, ölüm sonrasına etkili olması istenen bir iradenin şeklen tespiti biçiminde anlaşıldığ 1 açıktır. Bu tanımlara göre Roma vasiyetnamesinin iki özelliği saptanmalıdır: Birincisi, vasiyetnamenin ölüm sonrasına etki eden bir işlem olup öncesinde hak ya da borç doğurmayacak olması; ikincisi, tek taraflı bir irade açıllaması olup hüküm doğurmak için muhatabın kabul beyanına ihtiyaç göstermeyecek olmasıdır ${ }^{5}$.

Ölüm sonrasına etkili bir işlem olması sebebiyle, vasiyetnamenin, vasiyet edenin ölümü öncesi hak ya da borç doğuracak olması modern hukukta olduğu gibi Roma Hukukunda da kabul edilmemiştir. Vasiyetname düzenleyen kişi bu tasarrufu ile sağlar arası bir borç ya da yükümlülük altına girmediği gibi bu tasarruftan yararlanacak olanlar da sağlar arası, başka deyişle, güncel bir hak ya da menfaat elde etmiş olmazlar ${ }^{6}$. Vasiyetnamenin ölüm sonrasına etkililiği Roma Hukukunda o denli kesin bir dille kabul edilmiştir ki vasiyetnamenin ölüm öncesi hüküm doğurmasını sağlayacak tüm sağlar arası işlemler ahlaka aykırı sayılarak yasaklanmıştır ${ }^{7}$. Ölüm sonrasına etkili bir işlem olarak kabul edilmesinin bir başka sonucu da, vasiyetnamenin, tek taraflı bir irade açıklaması ile sonuçlarını doğuracak olup bu vasiyetnameden bir hak ya da menfaat sağlayacak olan mirasçı, vasiyet alacaklısı ve yükleme lehdarı gibi muhataplarının kabulüne ihtiyaç göstermeyecek olmasıdır ${ }^{8}$.

Vasiyetname kavramı Roma Hukukunda “testamentum” sözcügü ile ifade edilmiştir. Ancak sözcüğün etimolojik kökeni doktrinde tartışmalıdır. Bu sözcügün "testatio" ve "mentis” sözcüklerinin birleşmesinden meydana geldiğini düşündüren kaynaklar bulunduğu gibi ", "contestatio" ve "mentis" sözcüklerinin birleşmesinden meydana geldiğini düşündüren kaynaklar da vardır ${ }^{10}$. Sözlük anlamıyla ele alındığında her iki sözcük kalıbı da birbirinden farklıdır. Testatio mentis, "söze tanıklık

4 D. 28. 1. 1, (çeviri için bkz. Di Marzo S., s. 512).

$5 \quad$ Umur Z., Roma Hukuku Ders Notları, Tipkı 3. Basım, İstanbul, Beta Yayıncılık, 2010, s. 509; Günal, N., "Roma Miras Hukuku’na Genel Bir Bakış ve Vasiyet Yolu İle Miras”, Ankara Üniversitesi Hukuk Fakültesi Dergisi, C. 44, S. 1, 1995, s. 433. Roma hukukunda mirasın kazanılması için mirasçılar tarafından yapılması gerekli bir kabul işlemi vasiyetnamenin hüküm doğurması için değil mirasın kazanılması için gereklidir, vasiyetname mirasbırakanın ölümüyle birlikte kendiliğinden hüküm ifade eder, (vasiyetnamenin açılması hakkında bkz. Di Marzo S, s. 538-539).

6 Koschaker P./ Ayiter K., Modern Özel Hukuka Giriş Olarak Roma Özel Hukukunun Ana Hatları, İzmir, Dokuz Eylül Üniversitesi Hukuk Fakültesi Döner Sermaye İşletmesi Yayınları, 1993, s. 358-359.

7 Vasiyetnamenin ölüm öncesinde hüküm doğurmasını amaçlayan sağlar arası işlemlerin ahlaka aykırılık sebebiyle geçersiz sayıldığını D. 45. 1. 61 metninden anlıyoruz: "Stipulatio hoc modo concepta: «si heredem me non feceris, tantum dare spondes?», inutilis est, quia contra bnos mores est haec stipulatio ("Eğer beni mirasçın olarak atamazsan, bana şu kadar para ödemeyi taahhüt ediyor musun?» şeklinde yapılan stipulatio, ahlaka aykırı olduğu için geçersizdir)”, (çeviri için bkz. Küçükgüngör E, Testamentum, s. 55).

8 Umur Z, Ders Notları, s. 509. Bu noktada belirtilmesi gereken önemli bir husus vardır: Roma Hukuku söz konusu olduğunda mirasın kazanılması aşamasında muhataplar tarafından yapılması gerekli kabul işlemlerinin vasiyetnamenin hüküm doğurmasına bir etkisi yoktur, bu iki durumu birbirine karıştırmamak gerektir. Modern hukukumuzdan farklı olarak Roma Hukukunda mirasın açılması ile mirasın kazanılması aynı anda gerçekleşmez. Miras açıldıktan sonra tereke kendiliğinden mirasçılara (gönüllü mirasçılara) intikal etmeyip bunun için mirasçıların kabul beyanında bulunmalarına ihtiyaç vardır. Ancak bu mirasçılar tarafından yapılacak bir kabul işlemi, yukarıda da belirtildiği üzere, vasiyetnamenin hüküm doğurması açısından değil mirasın kazanılması açısından gereklidir; vasiyetnamenin hüküm doğurması mirasbırakanın ölümüyle kendiliğinden gerçekleşecek olup vasiyetnamenin kabulü işlemine gerek yoktur (Di Marzo S., s. 555 vd.).

9 Örneğin Ius. Inst., 2. 10 pr.

10 Örneğin Gellius Noctes Atticae 7 (6). 12. 1.2 (metin için bkz. Küçükgüngör E., Testamentum, s. 100. 
ediyorum" manasında iken; contestatio mentis, "iradeyi saptıyorum" manasındadır11. Etimolojik köken tartışmasında Schmidlin ve Cannata, testamentum sözcüğünün "söze tanıklık ediyorum" manasındaki testatio ve mentis sözcüklerinin birleşmesinden meydana geldiği fikrindedirler. Yazarlara göre bu anlamıyla testamentum teriminin vasiyetname kavramını tam olarak karşıladığı söylenemez fakat sahip olduğu hukuki değer de inkar edilemez, çünkü bu işlemin ağırlı̆̆ını ve önemini ortaya koyan ölenin son arzularına tanıklık edebilme fikridir ve testamentum sözcüğü de bunu vurgulamaya yeter düzeydedir ${ }^{12}$. Bunun yanı sıra contestatio mentis'in sadece kelimelerin yer değiştirmesinden ibaret ve anlam bakımından testatio mentis’ten farkı bulunmayan bir terim olduğu yolundaki eski bir düşünceyi de burada anmak gereklidir ${ }^{13}$. Monier ise bu sözcüğün Latinlerin kullandığ 1 "tristaamentud” sözcüğünden türemiş olabileceği düşüncesindedir. Yazara göre “tristaamentud” zamanla “tristamentom”a dönüşmüş, sonrasında “testamentum” biçimini alarak teorik bir anlama kavuşmuş olmalıdır ${ }^{14}$. Bizim fikrimize göre, Roma’da ilk vasiyetname şekillerinin törensel olduğu ve tanıklar huzurunda yapılan merasime bağlı niteliği düşünüldüğünde, iradenin tespiti ile iradeye tanıklığın aynı anlama geldiği kabul edilebilir çünkü tanıklar tarafından yapılan iş de nihayetinde son arzuların tespiti işinden başkası değildir.

Roma Hukukunda vasiyetname, mirasbırakanın ölüm sonrasında hüküm doğurmasını istediği tüm ölüme bağlı tasarruflarını kapsayan bir işlem olduğu için şeklî anlamda ölüme bağlı bir tasarruftur. Gerçekten vasiyetname, zorunlu içerik olarak mirasçı atama; zorunlu olmayan içerik olarak da vasi tayini, azat etme, belirli mal bırakma, yükleme gibi tasarrufları içine alan çerçeve bir tasarruftur ${ }^{15}$. Roma Hukukunda vasiyetname yukarıda temas ettiğimiz tariflerinde olduğu gibi ölüm sonrasındaki iradenin şeklen tespiti demek olduğuna göre bu iradeyi içine alan çatı veya çerçeve nitelikte bir işlem olup şeklî anlamda bir ölüme bağlı tasarruf niteliğindedir ${ }^{16}$.

Roma hukukunda vasiyetnamenin geçerli olması için hem şekle, hem de içeriğe ilişkin şartların tamamlanması icap eder. Şekle ilişkin şartlar bu çalışmanın da konusunu oluşturan şekil şartları yani vasiyetnamenin geçerli biçimde var olabilmesi için aranan törensel nitelikte bazı merasimlerdir. İçeriksel şart ise, maddi anlamda ölüme bağlı tasarruflardan biri olan mirasçı atamanın mutlak surette var olması ve vasiyetnamenin en başında yer alması zorunluluğudur ${ }^{17}$; nitekim mirasçı

11 Di Marzo S., s. 512-513 ve s. 512 dn. 2; Küçükgüngör E., Testamentum, s. 99-100.

12 Schmidlin B./ Augusto Cannata C., Droit Privé Romain, II, Obligations - Successions - Procédure, Lausanne, CJR, 1987, s. 210.

13 Bu düşünce için bkz. Di Marzo S., s. 512-513.

14 Monier R., Manuel Elémentaire De Droit Romain, Tome I, Introduction Historique, Les Sources - La Procédure - Les Personnes - Les Droit Réels-Les Successions, 6. éd., Editions Domat Montchrestien, 1947, s. 453.

15 Söğütlü Ö., Roma Özel Hukuku, Ankara, Seçkin Yayınevi, 2020, s. 243.

16 Şekli anlamda ölüme bağlı tasarruf-maddi anlamda ölüme bağlı tasarruf ayrımı için bkz. İmre Z. / Erman H., Miras Hukuku, Yasal Mirasçılık-Ölüme Bağlı Tasarruflar-Mirasın Geçmesi-Mirasın Taksimi, Gözden Geçirilmiş 14. basım, İstanbul, Der Yayınları, 2018, s. 55.

17 Gai. Inst., 2. 116. Roma hukukunda içeriksel şartlar ile ilgili bahsettiğimiz bu kuralların tek istisnası, asker vasiyetnameleridir. Mirasçı atama tasarrufuna yer vermemiş olsa bile asker vasiyetnameleri geçerli kabul edilmiştir, hatta asker vasiyetnameleri sadece bu bakımdan değil, diğer şeklî ve içeriksel şartlardan da arındırılmıştır. Bu bakımdan Roma hukukunda vasiyetname serbestisinin tam olarak ancak asker vasiyetnameleri açısından sağlanabildiği kesindir, (asker vasiyetnameleri hakkında ayrıntılı bilgi için bkz. Küçükgüngör E., Testamentum, s. 138 vd.). 
atamasını içermeyen bir vasiyetnamenin, şekil şartlarını yerine getirmiş olsa bile, hukuk dünyasında var olduğundan söz edilemez ${ }^{18}$.

Muhtevasında mirasçı atamanın yer almadığı bir vasiyetname yok hükmünde kabul edildiğinden Roma Hukukunda mirasçı atama tasarrufunun vasiyetnamenin kurucu unsuru olduğu açıktır. Roma Hukukunda mirasçı atamanın vasiyetnamenin zorunlu içeriği haline getirildiği Gai. Inst., 2. 229 metninde tespit edilmiştir ${ }^{19}$. Metinde, vasiyetnamenin başı ve temeli olarak kabul edilmesi nedeniyle mirasçı atama işleminden önce yazılan tüm tasarrufların geçersiz olduğuna işaret edilmektedir. $\mathrm{Bu}$ da Roma Hukukunda mirasçı atama tasarrufunun vasiyetnamenin kurucu unsuru olarak kabul edildiğinin açık bir göstergesidir. Ölüme bağlı tasarruf iradesi mirasçı atama tasarrufunda somutlaşabileceği için bu iradenin varlığı mirasçı atama iradesinin varlığına bağlanmıştır. Vasiyetname ile mirasçı atama arasındaki bu sıkı bağlılık karşılıklıdır, mirasçı atama vasiyetnamenin kurucu unsuru olduğu kadar vasiyetname de mirasçı atamanın kurucu unsurudur. Mirasçı atamanın bir ölüme bağlı tasarruf olması, bu tasarrufun salt vasiyetnamede açıklanmasını zorunlu kılar aksi halde bu işlem geçersiz olur ${ }^{20}$.

\section{Roma Hukukunda Vasiyetname Şekillerine Bakış}

\section{A. Genel Olarak}

Roma hukukunda vasiyetname şekilleriyle ilgili ortaya konması gerekli ilk tespit, bu şekillerin devirlere göre farklılık gösterdiğidir. Roma Hukukunda Eski Hukuk, Klasik Hukuk ve Postklasik Hukukta kabul edilen vasiyetname şekilleri birbirinden farklılık arz eder. Roma’nın bilinen en eski vasiyetname şekillerini Gaius ve Iustinianus'un Institutiones'indeki konuyla ilgili metinlerinden ${ }^{21}$ öğreniyoruz. Nitekim "Vasiyetnamelerin Tanzimi” başlıklı 10. kitabının principium'unda ${ }^{22}$ Iustinianus'un Institutiones'i, vasiyetnameyi "son arzuların açıklanması" olarak tarif ettikten sonra metnin devamında bu son arzuların nasıl beyan edileceğini açıklamaktadır. Metin şu şekilde kaleme alınmıştır:

18 Modern hukukta ise vasiyetname içeriğinde mutlaka maddi anlamda ölüme bağlı tasarrufların (gerçek anlamda) yer alması gerekmez (Kocayusufpaşaoğlu N., Miras Hukuku, Hiç Değiştirilmemiş 3. Bası, İstanbul, Filiz Kitabevi, 1987, s. 255 vd.). Gerçek anlamda birer maddi ölüme bağlı tasarruf sayılamayacak emir ve isteklerin de vasiyetname bünyesinde yer almasına cevaz verilir ve böyle bir vasiyetnameye de pekala geçerlik tanınır. $O$ halde günümüzde mesela sadece cenaze merasiminin nasıl olması gerektiğine dair bir vasiyetname de yapılabilir, fakat gerçek anlamda maddi ölüme bağlı tasarruf olmayan bu tasarrufun kanuni mirasçılar açısından bağlayıcı olması da beklenemez. Mirasçılar için bağlayıcı olan tasarruflar gerçek anlamda maddi birer ölüme bağlı tasarruf olup, bunlar Türk Medeni Kanununda ve özellikle de miras hukuku kitabında sayılanlardan ibarettir (ayrıca bkz. Kayak S., Roma Hukukunda İkame (Substitutio) ve Türk Hukuku Üzerindeki Etkisi, İstanbul, Filiz Kitabevi, 2019, s. 172-173.

19 Gai. Inst., 2. 229: Ante heredis institutionem inutiliter legatur, scilicet quia testamenta uim ex institutione heredis accipiunt, et ob id uelut caput et fundamentum intellegitur totius testamenti heredis institutio (Bir mirasçı atamasından önce mal vasiyet edilmesi geçersizdir, çünkü vasiyetnameler güçlerini mirasçı atama işleminden alırlar ve buna bağlı olarak mirasçı atama her vasiyetnamenin başı ve temeli olarak kabul edilir), (çeviri için bkz. Küçükgüngör E., Testamentum, s. 169 dn. 4).

20 Kayak S., s. 181.

21 Gai. Inst. 2. 101 ve Ius. Inst., 2. 10. 1

22 Ius., Inst., 2. $10 \mathrm{pr}$ 
Ius. Inst., 2. 10. 1

Sed ut nihil antiquitatis penitus ignoretur sciendum est, olim quidem duo genera testamentorum in usu fuisse, quorum altero in pace et in otio utebantur, quod calatis comitiis appellabatur, altero, cum in proelium exituri essent, quod procinctum dicebatur. accessit deinde tertium genus testamentorum, quod dicebatur per aes et libram, scilicet quia per emancipationem, id est imaginariam quandam venditionem agebatur, quinque testibus et libripende, civibus Romanis puberibus, praesentibus et eo qui familiae emptor dicebatur. sed illa quidem priora duo genera testamentorum ex veteribus temporibus in desuetudinem abierunt: quod vero per aes et libram fiebat, licet diutius permansit, attamen partim et hoc in usu esse desiit.

Ius. Inst., 2. 10. 1

Eski zamanların hiçbir şeyi bilinmemiş kalmasın diye, bir vakitler iki nevi vasiyetnamenin cari olduğunu bildiriyoruz: bunların birincisi sulh ve sükun zamanlarında kullanılırdı ve buna calatis comitiis (halk meclisleri önünde) vasiyetname denirdi; diğer muharebeye hazırlanırken yapılırdı ve procinctum (harbe hazır ordu önünde) vasiyetname ismini alırdı. Bilahare bunlara üçüncü bir nevi vasiyetname eklendi ki buna per aes et libram (külçe veterazi ile) vasiyetname denildi ve emancipatio ile, yani hayali bir alım satımla beş baliğ Roma vatandaşı, libripens (terazi tutan) ve familiae emptor (mamelekin alıcısı) denilen kimselerin huzurunda yapilırdi²

Metinde Roma'nın en eski vasiyetname şekillerinin testamentum calatis comitiis ve testamentum in procinctu olduğu bildirilmektedir. Testamentum calatis comitiis, barış zamanlarında ve günlük hayatın olağan akışı içinde yapılan olağan vasiyetname şekli; testamentum in procinctu ise, savaş gibi istisnai hallerde yapılan olağanüstü vasiyetname şeklidir. Zaman içinde pratik ihtiyaçlara bağlı olarak bu vasiyetname şekillerinde değişmeler meydana gelerek yeni vasiyetname türleri ortaya çımıştır ${ }^{24}$. Nihayet Iustinianus Hukukuna gelindiğinde vasiyetnamenin modern hukuktakine çok benzer biçimde resmi, yazılı ve sözlü vasiyetname olarak üç ayrı şekilde kurulabileceği kabul edilmiştir ${ }^{25}$.

\section{B. Eski Hukuk Devrinde Vasiyetname Şekilleri}

Eski Hukuk Devrinin bilinen en eski vasiyetname şeklinin barış zamanlarında testamentum calatis comitiis, savaş zamanlarında testamentum in procinctu olduğunu yukarıda metnini verdiğimiz Ius. Inst. 2. 10. 1'deki düzenlemeden öğreniyoruz. Iustinianus bu metinde bu vasiyetnamelerden bahsederken bunların en eski vasiyetname şekilleri olduğundan söz açmakta ancak bunlar hakkında

23 Çalışmamızda kullandığımız Iustinianus Institutiones metinlerinin çevirisi Iustinianus, Institutiones, Türkçe metin: Ziya Umur, İstanbul, 1984 adlı eserden alınmıştır.

24 Tahiroğlu B., "Quelques Ressemblances et Différences entre Le Droit Romain et Le Droit Moderne Turc Dans Les Droit Des Successions" Hukuk Araştırmaları Dergisi, C. 3, 1988, s. 8

25 Di Marzo S., s. 518-526. 
detay vermemektedir. Dolayısıyla bu vasiyetnamelerden açıkça söz eden ilk elden kaynak olduğuna tanık olsak da bu metnin söz konusu vasiyetnamelerin gerçek durumu ve hukuki nitelikleri hakkında bize yeteri kadar bilgi sağladığını söyleyemeyiz ${ }^{26}$. Buna bağlı olarak da Roma’nın Eski Hukuk Devrinde yürürlükte olan bu vasiyetnamelerin şekillerinin ve hukuki niteliklerinin doktrinde daima tartışmalı olduğunu belirtebiliriz.

Olağan zamanlarda cari olan testamentum calatis comitiis, curia ${ }^{27}$ ’lara ayrılmış halk meclisleri önünde 24 mart ve 24 mayıs tarihlerinde olmak üzere yılda iki defa düzenlenen merasimlerle yapılan törensel bir işlemden ibarettir ${ }^{28}$. Bu işlem, söz konusu tarihlerde, rahiplerin katılımı ile toplanan halk meclisleri önünde hazır bulunan vasiyet edenin, ölümünden sonra yerine geçecek kişinin kim olacağına dair iradesini açıklaması ile başlar ve bu iradenin rahipler ile halk meclisi tarafından onaylaması ile tamamlanırd ${ }^{29}$.

Testamentum calatis comitiis merasiminin nasıl yapıldığını gösteren metinler Gellius’a ait Noctes Atticae 15. 27. 1-3 $\operatorname{arasid}_{10}{ }^{30}$ :

Noctes Atticae 15. 27. 1-3

In libro Laelii Felicis ad Q. Mucium primo scriptum est, Labeonem scribere calata comitia esse, quae pro conlegio pontificum habentur aut regis aut flaminum inaugurandorum causa. Eorum autem alia esse curiata...; curiata per lictorem curiatum calari, id est convocari. Isdem comitiis, quae calata appellari diximus, et sacrorum detestatio et testamenta fieri solebant ${ }^{31}$.

Noctes Atticae 15. 27. 1-3

Elius Felix’in Q. Mucius’a ithaf ettiği eserin birinci kitabında Labeo'nun eserlerinde, cimitia calata’nın kral merasimlerinde veya Jüpiter'e ibadetlerde rahipler heyeti huzurunda toplandığının yazılı olduğu söylenmektedir. Comitiaların bazıları calata'dır... Bunlar lictor'lar

26 Küçükgüngör E., Testamentum, s. 124.

27 Curia; Romulus tarafından oluşturulduğu rivayet edilen ve sadece patricius'lardan oluştuğu düşünülen ve idare, seçim, din, askerlik gibi işlerle meşgul olan halk meclisinin en küçük ünitesidir. Eli silah tutan tüm erkek Roma vatandaşlarından oluşan halk meclisinin sosyal, siyasi ve askeri işlerle uğraşmak üzere meydana getirilmiş en küçük biriminin curia olduğu düşünülmektedir. Bu ayrım etnik kökenli olmayıp savunma ihtiacını karşılamak üzere savaşçı güçlerin gereken yerlere dağıtılması mecburiyetinden doğmuştur (Söğütlï Erişgin Ö., Roma Kamu Hukukuna Giriş, Ankara, Seçkin, 2017, s. 26). Üyelerinin tribus'lardan seçildiği curia'ların sayıları önceleri otuz iken bu sayı sonraları altmışa kadar çıkmıştır. Bu dönemdeki işlevini günden güne yitiren curia'ların Son İmparatorluk Dönemine gelindiğinde, vergi toplama işiyle meşguliyetten başka bir görevlerinin olmadığı tespit edilir (Umur Z., Lügat, s. 53).

28 Lepointe M., Cours de Droit Romain, rédigé d’apres les Notes et avec l’Autorisation, Licence 1 année, Paris, 1948-1949, s. 789; Cuq E., Manuel Des Institutionis Juridiques Des Romains, 2. éd., Revue Et Complétée, Paris, Librairie Plon/ Librairie Générale, 1928, s. 683.

29 Lambert J. N., "La Très Ancienne Succession Romaine Interprétée D’Après Le Droit Comparé”, RHD, 4. serie vol. 31, 1954, s. 500; Koschaker P./Ayiter K., s. 361; Umur Z., "Roma Miras Hukuku’nun Ana Hatları”, s. 10; Küçükgüngör E., Testamentum, s. 123-124.

30 Küçükgüngör E., Testamentum, s. 124.

31 Latince metin için bkz. Küçükgüngör E., Testamentum, s. 124. 
tarafından davet edilirlerdi ve bu calata dediğimiz comitia hem aile ibadetleriyle, hem de vasiyet yapılması ile iştigal ederlerdi ${ }^{32}$.

Testamentum calatis comitiis'in hukuki niteliği Romanist doktrinde ciddi ölçüde tartışmalıdır. Doktrinde bir görüş, testamentum calatis comitiis için öngörülen merasimin Roma Hukukunda bir tür evlat edinme işlemi olan adrogatio ile olan benzerliği nedeniyle testamentum calatis comitiis'in gelecekteki bir evlat edinme işlemi olduğu yolundadır ${ }^{33}$. Bu görüşe göre aralarındaki benzerlik nedeniyle testamentum calatis comitiis aslında mirasçının evlat edinilmesinden başka bir işlem değildir. Burada vasiyetname düzenleyen aslında kendi yerine geçecek bir külli halef tayin etmektedir. Bu işlemin adrogatio'dan tek farkı, adrogatio gibi sağlar arası bir işlem olmayıp ölüm sonrasına etki edecek olmasıdır ${ }^{34}$.

Ancak bu görüşe karşı çıkan yazarlardan Lambert, ilk biçiminde Roma vasiyetnamesinin bir evlat edinme işlemi olarak kabul edilemeyeceğini zira bunun için kaynaklarda yeterli bir destek bulunmadığını ifade etmektedir ${ }^{35}$. Evlat edinme görüşüne kaşı çıkan yazarlardan Appleton daha güçlü bir destek sunar. Yazara göre testamentum calatis comitiis'in evlat edinme işlemi olarak kabulünü Roma ailesinin dini gelenekleri engeller. Bu çağda aile kültünü devam ettirme düşüncesi vardır ve aile kültünü belirleyen de sacra yani dini geleneklerdir. Vasiyetname yoluyla atanmış mirasçı aile kültünün de devam ettiricisi olacağından başka bir aileye, dolayısıyla sacra'ya mensup olan kimsenin, evlat edinilebilse bile, vasiyetname yoluyla mirasçı olarak atanması düşünülemez. Başka bir aileye mensup olan kimsenin evlat edinilerek mirasçı atanması ancak bu kimsenin kendi aile hakimiyetinden çıkıp bu aileye dahil olmasıyla mümkündür; oysaki kaynaklarda bu durumdan açıkça söz eden bir metin ya da bilgiye rastlanmaz ${ }^{36}$.

Bir başka görüşe göre ise testamentum calatis comitiis, kamu otoritesinin onayına ihtiyaç göstermesi ve sağlar arası bir işlem olan adrogatio'ya benzemesi nedeniyle gerçek anlamda bir vasiyetname olarak nitelendirilmekten çok dinsel ve politik bir kurum gibi ele alınmalıdır. Bu görüşü savunan Boissarie’ye göre, bu işleme hukuksal anlamda bir nitelik vermek gerekirse ona özel hukukta değil kamu hukukunda bir anlam yüklemek ve kamu hukuku alanında da "yasa" mahiyetinde bir nitelik atfetmek gerektir. Açıç̧ası yazara göre testamentum calatis comitiis kamu otoritesinin

32 Metnin çeviri için bkz. Küçükgüngör E., Testamentum, s. 124.

33 Cuq E., s. 683; Di Marzo S., s. 519; Koschaker P./Ayiter K., s. 363, ayrıca bkz. Küçükgüngör E., Testamentum, s. 125.

34 Koschaker P./Ayiter K., s. 363.

35 Lambert E., La Tradition Romaine Sur La Succession Des Formes Du Testament Devant L'Histoire Comparative, Paris, V. Giard \& E. Brière Librairies Editions, 1901, s. 25.

36 Appleton Cf., Le Testament Romain, La Méthode Du Droit Comparé et L'Authénticité Des XII Tables, 1903, s. 69'dan nakleden: Lévy-Bruhl H., "La Fonction Du Très Ancien Testament Romain", NRHD, vol. 45, 1921, s. 643. Evlat edinme görüşündeki yazarlar bu yöndeki eleştirilere cevap olarak Romảnın eski vasiyetname şekillerinin mirasçı atama kurumunu içermeyip belirli mal bırakma, azat etme gibi başka düzenlemelere yer vermiş olduğunu gerekçe göstermektedirler. Mirasçı atama, çok sonraları, mancipatio familiae ile işlerlik kazanmıştır. Buna en büyük destek On İki Levhada geçen "uti legassit...ita ius esto" (XII Tab., v. 3) cümlesindeki "legare” sözcügüdür. Teknik anlamda "belirli bir malı vasiyet etmek” anlamına gelen bu sözcükle belirli mal bırakma tasarrufları kastedilmiştir, mirasçı atamadan ise söz edilmemiştir. On İki Levha Kanunlarının kendisinden önceki örf ve adetleri derleyen bir düzenleme olduğu düşünüldüğünde Roma’nın en eski vasiyetname biçimlerinde mirasçı atamaya yer verilmediği açıtır (Cuq E., s. 682). 
yasa niteliğindeki bir tasarrufundan ibarettir ${ }^{37}$. Yazar bu görüşüne dayanak olarak pek çok kanıt göstermektedir. Bunların başında Romalıların testamentum sözcügüne yükledikleri anlam gelir, zira yazara göre bu sözcük Roma’nın ilk zamanlarında basit bir tanıklıktan öte bir anlama, enerjik ve güçlü bir anlama sahiptir ${ }^{38}$. İlk zamanlarda Roma’da, evlat edinme ve mancipatio gibi pek çok hukuki işlem için gerekli olan kamusal otoritenin müdahalesi unsuru vasiyetname için de gereklidir. Bunun nedeni, vasiyet edenin, ölüm sonrasındaki arzularına sadık kalınacağına dair mutlak bir teminat elde etmekti ve bu teminatı sağlayacak olan da halk meclisinin onayı idi. Comitia’nın ${ }^{39}$ bir tür "oy/rey vermek" olarak nitelendirilebilecek bu onayı işlemin hukuk dünyasında var olmasını sağlıyor ve bu da bu işlemi yasal bir düzenleme seviyesine çıkarıyordu. Başka deyişle comitia’nın verdiği her onay, müteveffa tarafından hazırlanan bu vasiyetnamenin herkes için uyulması zorunlu genel geçer nitelikte ve dolayısıyla mutlak anlamda bir düzenlemeye, bir "yasa”ya dönüşmesini sağliyordu ${ }^{40}$. Boissarie’ye göre ayrıca, On İki Levha Kanunlarından ${ }^{41}$ önce örf ve adet hukukunda var olan bu uygulama bu yasalarla yazılı hukuka geçildikten sonra da korunmuştu ${ }^{42}$. Vasiyet edenin bu işlemdeki fonksiyonu "legare/vasiyet etmek" olarak isimlendirilerek ve bu düzenlemelerin emredici olduğu kabul edilerek sonradan vasiyet eden tarafından dahi değiştirilmesine izin verilmemiştir. $\mathrm{Bu}$ da testamentum calatis comitiis'in yasa niteliğinde olduğunun açık bir kanıtıdır ${ }^{43}$. Testamentum calatis comitiis'in yasa mahiyetinde bir düzenleme olduğuna başka bir kanıt, ilk dönemlerde görülen katı şekilcilik anlayışının vasiyetname için de geçerli olmasıdır. Formüller, sembolik işlemler ve merasimler vasiyetnameler için de geçerli olup, bu da, bu mahiyetteki bütün işlemlerin yasa niteliğine büründüğünün bir göstergesidir ${ }^{44}$. Yine vasiyetnamede vaat edilen şeylerin devir ve temlik işlemlerine gerek kalmaksızın ipso iure kazanılması da Roma'da vasiyetnamenin ilk şeklinin

37 Boissarie R., Des Formes Du Testament Romain, Paris, L. Larose Et Forcel, 1888, s. 7 vd.

38 Boissarie R., s. 14.

39 Roma Hukukunda halk meclisleri çeşitli türlere ayrılmaktadır. Burada bahsedilen halk meclisi comitia curiata olmalıdır (Roma’da halk meclisleri hakkında bkz. Türkoğlu, G. H., "Roma Cumhuriyet ve İlk İmparatorluk Dönemlerinin İdari Yapısı”, Dokuz Eylül Üniversitesi Hukuk Fakültesi Dergisi, C. 11, S. 2, 2009, s. 278-279.

40 Boissarie R., s. 14-16. Aynı yönde Berki Ş., Roma Hukuku, Ankara, Ankara Üniversitesi Hukuk Fakültesi, 1949, s. 181 (Yazar halk meclislerinin onay verme yetkisinin ancak arrogatio/adrogatio halinde mevcu olduğunu da ayrıca vurgulamaktadır).

41 On İki Levha Kanunları Roma’nın bilinen ilk kanunlaştırma hareketidir. Cumhuriyet devrinin ilk yıllarında (M.Ö. 451-449) yapıldığı tahmin edilen ve toplam on iki levhadan oluştuğu için Romanist doktrinde bu isimle anılan On İki Levha Kanunları o zamana kadar yazılı olmayan ve daha çok örf ve adet kuralı şeklinde uygulanan kuralları derleyerek yazılı hale getirmiştir. Böylece pleb sınıfı da dahil, herkesin hukuk kurallarına ulaşması sağlanmış, patricius ve bu sınıfa mensup rahip hukukçuların hukuk kurallarını kendi gizli tekellerinde tutmaları ve bu yolla da, daima kendi lehlerine yorumlamaları büyük ölçüde önlenmiştir. İpek N., "XII Levha Kanunu”, Argumentum, Yıl: 3, Sayı: 34, s. 609 vd.

42 XII Tab., v. 3: “Uti legassit...ita ius esto (nasıl vasiyet ederse ...hukuk öyle olsun)”, metin ve çevirisi için bkz. Sandalcı S., On İki Levha Yasaları, Yayımlanmamış Yüksek Lisans Tezi, İstanbul, İstanbul Üniversitesi Edebiyat Fakültesi, 1993, s. 28 ve s. 48 .

43 Boissarie R., s. 16. Ancak bu noktada Lambert, On İki Levhada geçen “uti legassit...ita ius esto" ifadesinin sadece pecunia, yani para ile ölçülebilen bir değeri konu alan belirli mal birakmalarla ilgili olduğunu söylemektedir. Nitekim yazara göre On İki Levha Kanunları aile kültünün ve aile malvarlığının bir kül olarak intikali bakımından örf ve adet hukukunda var olan düzeni aynen yürürlükte bırakmıştı (Lambert E., s. 33).

44 Aynı yönde Accarias C., Précis De Droit Romain, Tome I, 4. Édition, Librairie Cotillon, 1886, s. 848.Nitekim yasa olarak kabul edildiği ölçüde vasiyet edenin ölüme bağlı tasarruf özgürlüğü desınırlandırılmış olur (Accarias, C., s. 848). Roma ve Türk hukukunda ölüme bağlı tasarruf özgürlüğühakkında karşılaştırmalı olarak bkz. Koca Ö., Roma Hukuku’nda ve Türk Hukuku’nda ÖlümeBağlıTasarrfular, Ankara, Yetkin Yayınları, 2018 
yasa olduğuna başka bir kanıttır ${ }^{45}$. Daha güçlü diğer bir kanıt, Romalıların özel hukuk alanındaki işlemlerinin derhal hüküm doğurucu nitelikte kabul edilmesine karşılık vasiyetnamenin ölüm sonrasında hüküm doğuracak surette kabul edilmesidir. Gerçekten de sağlar arasında bir hukuki işlem yapılır yapılmaz hükümlerini doğurmaya başlar, hükümleri geciktirmenin tek yolu şart ya da vade kurumlarından yararlanmaktır. Oysaki vasiyetnamede şart ya da vadeye bağlanmasa da gelecekte hüküm ifade edecek bir karakter vardır. Vasiyetname vasiyet edenin ölümünden sonra hükümlerini doğurmaya başlayacaktır, o zamana kadar askıdadır. Bu da vasiyetnamenin, tıpkı yasa gibi, yapıldığı andan ileriye doğru etki eden bir işlem olduğunu, dolayısıyla da yasa olduğunu gösterir. Yine, Roma hukukunda vasiyetnamenin ve bunun ilk şekli olan testamentum calatis comitiis'in yasa olduğunun bir başka kanıtı da, bu düzenlemenin basit bir hukuki işlemden ibaret olmayıp birden fazla hukuki işlemi içine alan bir tasarruf olmasıdır. Gerçekten de vasiyetname çok çeşitli düzenlemeleri içine alabiliyordu; mirasçı atama, vasi tayini, legatum bunlardan sadece bazılarıydı ${ }^{46}$.

$\mathrm{Bu}$ noktada Boissarie şu soruyu sormaktan kendisini alamadığını da bildirmektedir: Roma halkı neden bu işlemleri ayrı ayrı yapmak yerine bunları adına vasiyetname denen tek bir işlemin çatısı altında birleştirmeyi ve bu şekilde tasarrufta bulunmayı tercih etmişti? Neden tıpkı yasa gibi vasiyetnamede de birden fazla işlem tek bir formun altına sokulmuştu? Yazara göre bunun cevabı şu olabilir: Roma halkı vasiyetname işlemiyle bu işleme basit bir tanıklık yapmaktan daha fazlasını hedeflemekteydi; Roma halkı vasiyet edenin iradesini öğrenmeyi, tartışmayı ve duruma göre kabul veya reddetmeyi arzulamaktayd ${ }^{47}$.

Biz de testamentum calatis comitiis'in kamusal bir işlem niteliğinde olduğu fikrini kabul ediyoruz. Bu noktada vasiyetnamenin ve onun ilk şekli olan testamentum calatis comitiis'in bir yasa mahiyetinde olduğu fikri de kabul edilebilir, zira bunun için yukarıda Boissarie tarafından dile getirilen kanıtlar oldukça inandırıcı niteliktedir. Ancak yasa niteliği bu dönemde sadece vasiyetname için değil adrogatio gibi halk meclisinin müdahalesini gerektiren tüm hukuki işlemler bakımından geçerli olacaktır. Bu sebeple biz, ilave olarak, bu vasiyetnamenin adrogatio kapsamında ele alınan ve onun tamamlayıcısı durumunda bir işlem olduğunu da düşünüyoruz. Çünkü ilk zamanlarda aile reisinin kendi yerine geçecek kişiyi bizzat tayin etmesine lüzum olmayıp en büyük erkek evlat babaya haleftir ${ }^{48}$ ve bunun için bir vasiyetname düzenlemeye de lüzum yoktur. Fakat erkek evladı bulunmayan bir aile reisi için aynı şey söylenemez, bu durumdaki aile reisi için ölümünden sonraki halefini belirlemek önemlidir ${ }^{49}$ ve böyle bir aile reisi için tek seçenek sui iuris bir kimseyi evlat edinmektir ${ }^{50}$. Adrogatio yoluyla evlat

45 Boissarie R., s. 17.

46 Boissarie R., s. 17-19.

47 Boissarie R., s. 18. Çok net olmamakla birlikte, yazarın sonraki açıklamalarından, Roma halkının bu arzusunun vasiyetnamenin Roma örf ve adetleriyle uygunluk taşıması kaygısından doğmuş olabileceği düşüncesinde olduğunu anliyoruz, (Boissarie, s. $18 \mathrm{vd}$.).

48 Bu konuda bkz. ayrıntı için Koschaker P./Ayiter K., s. 344; Küçükgüngör E., "Roma ve Türk Hukukunda Muayyen Mal Vasiyeti”, Ankara Üniversitesi Hukuk Fakültesi Dergisi, C. 45, S. 1, 1996, s. 506.

49 Roma Hukukunda aile kültünün devamının arz ettiği önem hakkında bkz. Somer, P., "Dar anlamda Aile Hukukunun Esasları", Maltepe Üniversitesi Hukuk Fakültesi Dergisi, C.1 S.2, 2002, s.155 vd.

50 Evlat edinme kurumu Roma toplumunda özellikle doğal üreme oranı düşüklügünü telafi etmek ve ailenin yok olma tehlikesini bertaraf etmek amacıyla kullanılıyordu (İpek N., "Roma Hukukunda Hisımlık", MÜHF-HAD, C. 21, S. 1, s. 181. 
edinme işlemi yapan aile reisi bu suretle kendisine bir evlat edinmekten başka ölümünden sonra yerine geçecek, aile ilişkilerini devam ettirecek bir külli halefi de tayin etmiş olurdu. Koschaker de, burada önce adrogatio, sonra testamentum calatis comitiis olmak üzere iki ayrı işlem yerine, aynı amaca hizmet eden tek bir işleme, testamentum calatis comitiis’e başvurulmakla yetinildiğini ve böylece evlat edinme ve külli halef tayininin testamentum calatis comitiis bünyesinde birleştiğini tahmin etmekle bizim görüşümüze dayanak oluşturmaktadır ${ }^{51}$.

Testamentum calatis comitiis bakımından tartışılan bir başka husus, pontifex'in (baş rahip) onayının niteliğinin ne olduğudur. Bu onayın ne anlama geldiği konusundaki bilgilerimiz oldukça yetersizdir. İleri sürülen bir görüşe göre pontifex'in onayı bir tür kontrol mekanizmasıdır. Tıpkı adrogatio'da olduğu gibi bu hukuki işlemde de pontifex, paterfamilias'ın bu düzenlemesinin sebep ve şartları bakımından Roma yasalarına bir aykırılığın bulunmadığına, bu sebep ve şartların gerçek olduğuna dair teyitte bulunurdu ve bu suretle vasiyetname metni üzerinde Roma örf ve adetlerine uygunluk bakımından bir denetim sağlanmış olurdu ${ }^{52}$.

Eski Hukuk Devrinde geçerli olan, ancak sadece savaş zamanlarında devreye girmesiyle istisnai bir nitelik taşıyan testamentum in procinctu ise bu özelliği ile olağandışı bir vasiyetname türüdür ${ }^{53}$. "Hücuma hazır ordu önünde" anlamına gelen testamentum in procinctu, savaşa katılan askerlerin savaşa karar verilmesinden hemen sonra ve birbirleri önünde hiçbir şekle uyulmaksızın merasimsiz ve sözlü olarak yaptıkları bir vasiyetnamedir ${ }^{54}$. Testamentum in procinctu aslında hücuma hazır bir ordu önünde yapılması nedeniyle şekle bağlı olmayan asker vasiyetnamelerinin özel bir türü gibi düşünülebilir. Testamentum in procinctu’nun geçerli olmasının tek şartı, askerlerin yaptıkları bu beyanların, onların son arzularını içerdiğinin hiçbir şüpheye yer bırakmayacak şekilde anlaşılıyor olmasidir ${ }^{55}$.

\section{Klasik Hukuk Devrinde Vasiyetname Şekilleri}

\section{Testamentum Per Aes Et Libram Öncesi Dönem}

On İki Levha Kanunlarından beri mevcut bulunan bu iki vasiyetname şekli, Cumhuriyet Döneminin sonlarından itibaren yerlerini giderek başka bir vasiyetname türüne, per aes et libram testamentum'a bırakarak zamanla gözden kaybolmuşlardır ${ }^{56}$. Testamentum per aes et libram'ın ortaya çıkış nedeni

51 Koschaker P./Ayiter K., s. 363.

52 Lepointe G., Droit Romain Et Ancien Droit Français, Régimes Matrimoniaux, Libéralités, Successions, Paris, Editions Montchrestien, 1958, s. 15 N. 23. Lepointe, comitia'nın onayını da kamusal bir onay gibi belirlerken bu onayın işlemin daha çok ahlaki nitelemesi bakımından yapıldığını söylemektedir. Bu onay pontifex’in onayından farklı olarak bağlayıcı niteliktedir, çünkü düzenlenen vasiyetnamede Roma toplumu ahlaka aykırı bir husus görecek olursa bu vasiyetnameyi reddederek yürürlüğe girmesini engelleyebilirdi (Lepointe G., s. 15 N. 23). Bu onay unsurunun, gerek pontifex gerek halk meclisinin onayı bakımından kurucu mu yoksa tamamlayıcı mı olduğu hususu da yine buna ilave olarak net değildir, (bu konudaki tartışmalar için bkz. Lévy-Bruhl H., s. 636.

53 Accarias C., 849.

54 Boissarie R., s. 36-38; Di Marzo S., s. 518-519; Küçükgüngör E., Testamentum, s. 123-124.

55 Umur Z., "Roma Miras Hukuku'nun Ana Hatları" s. 10.

56 Koschaker P./Ayiter K., s. 362 vd.; Umur, "Roma Miras Hukuku’nun Ana Hatları” s. 10. 
testamentum calatis comitiis' in günlük hayatın pratik ihtiyaçlarına cevap vermedeki yetersizliklerine bağlanmaktadır ${ }^{57}$. Sıkı şekil şartlarına ve merasimlere bağlı oluşu, yılda ancak iki defa yapılabiliyor olması yüzünden süreyi kaçıran ya da ölümü aniden vuku bulup da vasiyetname yapmaya fırsat bulamayan paterfamilias'ların terekelerinin agnatio hısımlarına ya da başka gens'ten olan kimselere kalması gibi sakıncalar calatis comitiis'i gözden düşürüyordu. Yine, ticari ilişkilerin artması ve ulaşım olanaklarının da yaygınlaşmasına paralel olarak Roma dışına seyahatlerin başlaması ve uzun yolculuklar nedeniyle calatis comitiis vasiyetnamenin tanzim tarihleri olan 24 mart ya da 24 mayss tarihlerine yetişilemiyor olması da Romalıları yeni vasiyetname biçimleri aramaya yöneltiyordu. $\mathrm{Bu}$ arayışların neticesi "per aes et libram testamentum" adıyla bilinen yeni bir vasiyetname şekli ortaya $c_{\text {çktı }}{ }^{58}$. Oldukça karışık bir usulde olan ve henüz bu iki vasiyetname şekli yürürlükten kalkmadan uygulanmaya başlanan bu vasiyetname şeklinin köklerinin On İki Levha Kanunlarına götürülebileceği de bir görüş olarak ileri sürülmüştür ${ }^{59}$. İlk ortaya çıkış nedeninin comitia'ların toplanmasını bekleyemeyecek kadar yaşlı ve hasta olanlara vasiyetname yapma olanağını sağlayabilmek olduğu fakat sonraları Romalılar arasında yaygınlaştığı ve nihayet günümüzün vasiyetnamesi gibi tek taraflı bir işleme dönüştüğü ifade edilmektedir ${ }^{60}$.

Ancak tam bu noktada doktrinde mevcut bir tartışma nedeniyle bir parantez açmak gereklidir. Calatis comitiis vasiyetnamenin sakıncalarını gidermek için ortaya çıktığı öne sürülen bu yeni vasiyetname biçimi gerçekten testamentum per aes et libram mıdır yoksa ondan çok daha önce mancipatio familiae adıyla bilinen bir vasiyetname şekli daha mevcut olmuş mudur? Mancipatio familiae bakımından pek çok sorun olmakla birlikte asıl sorun bunun per aes et libram vasiyetname ile aynı mı, yoksa ondan farklı mı olduğudur. Per aes et libram vasiyetname ile familiae mancipatio'yu aynı anlamda ele alan bazı eserlerin varlığı gözden kaçmaz ${ }^{61}$. Bununla birlikte bu iki vasiyetnameyi farklı hukuki işlemler olarak düşünen ve mancipatio familiae’ın testamentum per aes et libram öncesinde mevcut olduğunu kabul edenler daha fazladır ${ }^{62}$. Mancipatio familiae' 1 per aes et libram'ın bir parçası ya da başka şekildeki bir ifadesi olarak görmeyip ayrı bir vasiyetname türü olarak ele alan yazarlar bu vasiyetnamenin dayanağını, az sonra açıklayacağımız, Gai. Inst. 2. 102 olarak göstermektedirler ${ }^{63}$. Ancak biz metne baktığımızda mancipatio familiae ifadesinin değil testamentum per aes et libram tabirinin geçtiğine tanık oluyoruz. Bize göre, salt söze göre bir yorumdan hareket edilecek olursa, her ikisinin de aynı hukuki işlem olduğuna kanaat getirmek daha yerinde olur. Ancak çoğunluk yazar bu iki işlemin arasında farklılık olduğunu Gai. Inst., 103 ve 104 gibi devamı metinleri de dikkate almak suretiyle kabul etmektedirler ${ }^{64}$. Mesela Lévy-Bruhl, per aes et libram'daki familiae emptor'un artık siradan bir alıcı olmayıp mirasçı sıfatını taşıdı̆̆ını ve mancipatio familiae’nın ancak bu andan itibaren per aes et

57 Accarias C., s. 850. Halk meclisleri önünde yapılan vasiyetnamelerin genel olarak pratik hayattaki eksikyanlarına dair bkz. Cuq E., s. 684.

58 Boissarie R., s. 39-40; Küçükgüngör E., Testamentum, s. 125.

59 Bu konuda bkz. Umur Z., Ders Notları, s. 510.

60 Umur Z., Ders Notları, 510.

61 Örneğin Lepointe G., s. 56 N. 102; Umur Z., Lügat, s. 131-132; muhtemelen Di Marzo S., s. 522.

62 Örneğin Cuq E., s. 684.

63 Cuq E., s. 684.

64 Cuq E., s. 684; Monier R., I, s. 458-459. 
libram testamentum’a dönüştüğünü ileri sürmektedir ${ }^{65}$. Hakim kanaat kabul edilecek olursa mancipatio familiae’ı testamentum per aes et libram’n bir aşaması olarak değil ayrı bir vasiyetname şekli olarak görmek gerekecektir.

Mancipatio familiae bakımından bir başka tartışma noktası, bu işlemin gerçekten ölüme bağlı bir işlem olarak nitelendirilip nitelendirilemeyeceği meselesidir. Bu tartışma aslında bu işlemin ayrı bir vasiyetname türü olarak kabul edilip edilemeyeceği tartışmasına da bağlıdır. Bu konuda ileri sürülen bir görüşe göre ise mancipatio familiae'da teknik anlamda bir mirasçı ataması yapılmış olmayip tahta levhalar üzerine yazılan istekler belirli mal bırakmalardan ibarettir, bu nedenle bu işlem ancak bir legatum vasiyetnamesi olarak karakterize edilebilir ${ }^{66}$. İleri sürülen bir başka görüş de, burada atanan familiae emptor'un mirasçıdan ziyade vasiyeti yerine getirme görevlisi niteliğinde olduğunu kabul etmektedir. Zira familiae emptor’a devredilen şey aslında terekenin mülkiyeti değil zilyetliğidir. Benzer durum Alman Hukukundaki "Salman” kurumunda da görülür. Bu bakımdan familiae emptor aslında bir vasiyeti yerine getirme görevlisinden başkası değildir ${ }^{67}$. Mancipatio familiae'yı ölüme bağlı bir işlem olarak kabul etmeyen Boissarie’ye göre ise, mancipatio familiae, her ne kadar bağımsız bir işlem olarak kabul edilirse de ölüme bağlı niteliği asla kabul edilemez, bu, tam anlamıla sağlar arası bir işlemdir. Mancipatio familiae'da vasiyet eden kimse, iradesini ölüm sonrasına etki ettirmek için ölüm sonrasında bu iradenin gereğini yerine getirecek olan kişiye tüm malvarlığını daha şimdiden, ölüm öncesinde devretmek zorundadır ${ }^{68}$. Oysaki vasiyetname dediğimiz işlem Roma’da daima iki karaktere sahip olmak zorundadır: Külli halefiyet yoluyla intikal sağlaması ve mirasçı atama tasarrufunu mutlak olarak içermesi ${ }^{69}$. Mancipatio familiae ise sadece cüzi bir intikal yoludur. Yapılan mancipatio işlemi ile res mancipi ${ }^{70}$ mallar devredilmekte olup ayni hak ya da alacakların temliki için mancipatio merasimleri uygun değildir. Buna bağlı olarak da mancipatio familiae'da malvarlığını devralan familiae emptor mirasçı sıfatını taşımaz, onun herhangi bir satı̧s sözleşmesindeki herhangi bir alıcıdan bir farkı yoktur ${ }^{71}$. Bu özelliklerine bağlı olarak calatis comitiis ölüm sonrası hüküm doğuran bir işlem, dolayısıyla bir vasiyetname olduğu halde, mancipatio familiae, sağlar arası hüküm doğuran bir işlemdir. Şu halde mancipatio familiae’ın calatis comitiis'in yerini vasiyetname anlamında dolduran bir işlem olduğunu söylemek çok zordur. $\mathrm{O}$ halde testamentum calatis comitiis' in sakıncaları yeni bir vasiyetname biçimi yaratmak yoluyla değil, mevcut kurumlardan yararlanmak suretiyle giderilmiş olacaktır. Bu bakımdan bizim de katıldığımız bu kanaate göre mancipatio familiae'ın calatis comitiis' in sakıncalarını giderdiği ve pratik ihtiyaçlara

65 Lévy-Bruhl H., s. 662.

66 Lambert J. N., s. 501-502.

67 Koschaker P./Ayiter K., s. 363. Karşılaştırmalı hukuk açısından bu tartışma için bkz. Lambert E., s. 65. Mancipatio familia’nın Roma Hukukunda miras sözleşmesi fonksiyonunda olduğu hakkında ayrıca bkz. Michaélides-Nouaros G., Contribution A L'Etude Des Pactes Successoraux et Droit Byzantin, Justinien et Post-Justinien, Paris, 1937, s. 44.

68 Boissarie R., s. 42. Aynı yönde Lévy-Bruhl H., s. 662.

69 Bu konuda bkz. Günal N., s. 435; Küçükgüngör E., Testamentum, s. 99 vd.

70 Res mancipi mal; İtalya arazisi, İtalya arazisi üzerindeki tarımsal irtifaklar, köleler, yük ve çekihayvanlarıdır (Söğütlü Ö., s. 240 dn. 90).

71 Boissarie R., s. 47. 
cevap verdiği söylenebilir ancak calatis comitiis'i yürürlükten kaldırıp onun yerine geçen ölüme bağlı bir işlem olduğu söylenemez ${ }^{72}$.

Mancipatio familiae'da familiae emptor bir mirasçı konumunda değildir, zira o, vasiyet edenin malvarlığını kendi mülkiyetinde daimi olarak muhafaza amacıyla değil, mancipans tarafından irade edilen kişilere dağıtmak amacıyla kazanır. Gai. Inst. 2. 102 ve 103’ten anlaşılıyor ki bu kişi malvarlı̆̆ının kendisine emanet edildiği güvenilir bir kişi, emin bir dosttan başkası değildir ${ }^{73}$. Familiae emptor bir alıcı konumunda olmakla birlikte legatum, azat etme, vasi tayini gibi yükümlülüklerle de kayttlanabilir. Bununla birlikte bu yükümlülüklerin mirasçıya yüklenen bir borç niteliğinde olduğunu kabul oldukça zordur zira familiae emptor bu yükümlülükleri yerine getirmek istemediği zaman onu ifaya zorlayacak bir mekanizma yok gibidir. Gai. Inst., 2. 102'de "rogabat (rica ediyorum)" ve 103'te de "mandabat (talimat veriyorum)" sözcükleri geçmektedir. Rogabat/rogare ifadesi dikkate alındığında mancipans’ın iradesinin familiae emptor için bağlayıcı olmadığı, bu iradenin gereğini yerine getirip getirmemekte serbest olduğu sonucu çıkar ki şu durumda mancipans'ın istekleri sadece bir ricadan ibarettir. "Mandabo/mandare" sözcükleri dikkate alındığında ise, ilk etapta familiae emptor'un kendisine mancipans tarafından bir talimat verildiğini ve bu talimat ile bağlandığını düşünmek haklı olabilirse de buradaki “mandare” sözcügünün vekalet sözleşmesindeki teknik anlamının dışında kullanıldığını kabul daha uygun düşer, çünkü Roma Hukukunda ölüm sonrası vekalet (mandatum post mortem) kaide olarak geçersizdir ${ }^{74}$.

\section{Testamentum Per Aes Et Libram}

Testamentum per aes et libram ile ilgili bilgileri asıl olarak Gai. Inst., 2. 102 ve 103'ten öğreniyoruz. Metinler şu şekilde kaleme alınmıştır:

Gai. Inst., 2. 102

Accessit deinde tertium genus testamenti, quod per aes et libram agitur: qui enim neque calatis comitiis neque in procinctu testamentum fecerat, is, si subita morte urguebatur, amico familiam suam, id est patrimonium suum, mancipio dabat eumque rogabat, quid cuique post mortem suam dari uellet. quod testamentum dicitur per aes et libram, scilicet quia per mancipationem peragitur.

Gai. Inst., 2. 102

Daha sonra külçe ve terazi ile yapılan üçüncü bir vasiyetname türü tanındı. Comitia calata önünde veya savaşa girmeden önce vasiyetname yapmamış olan kişi, ani bir ölüm endişesi içinde olduğunda, malvarlığını mancipatio ile bir arkadaşına devreder ve bu arkadaşından, ölümünden sonra kendi talimatına göre belirlediği kişilere bu malları dağıtmasını isterdi

72 Boissarie R., s. 39-59.

73 Boissarie R., s. 44.

74 Boissarie R., s. 44-45. Roma Hukukunda ölüm sonrası vekalet hakkında ayrıntı için bkz. Karagöz H., "Roma Hukukunda Mandatum Post Mortem (Ölümden Sonra Vekalet)”, Prof. Dr. Nihal Uluocak’a Armağan, İstanbul, 1999, s. $165-178$. 
(rica ederdi). Bu tür vasiyetnameye, mancipatio ile yapıldığı için testamentum per aes et libram (külçe ve terazi ile vasiyetname) adı verilir ${ }^{75}$.

Gai. Inst., 2. 103

Sed illa quidem duo genera testamentorum in desuetudinem abierunt; hoc uero solum, quod per aes et libram fit, in usu retentum est. sane nunc aliter ordinatur, quam olim solebat; namque olim familiae emptor, id est, qui a testatore familiam accipiebat mancipio, heredis locum optinebat, et ob id ei mandabat testator, quid cuique post mortem suam dari uellet; nunc uero alius heres testamento instituitur, a quo etiam legata relinquuntur, alius dicis gratia propter ueteris iuris imitationem familiae emptor adhibetur.

Gai. Inst., 2. 103

Bununla birlikte önceki iki vasiyetname şekli uygulamadan kalkmış, geride sadece testamentum per aes et libram kalmıştır. Ancak şu andaki usul, eski dönemlerden oldukça farklıdır. Zira önceleri familiae emptor, yani malvarlığını vasiyetnameyi yapan kişiden mancipatio ile devralan kişi mirasçı konumunda olurve böylece vasiyet eden, ölümünden sonra malvarlığını dağıtması konusunda oma talimat verirdi. Buna karşılık günümüzde bir başka kimse, vasiyetname ile mirasçı atanır ve bu kişi legatum'ların gereğini yapmakla yükümlü olur. Bu kişi sadece isim olarak, eski hukukun taklidi anlamında familiae emptor olarak nitelendirilir ${ }^{76}$.

Testamentum per aes et libram, mirasbırakanın malvarlığını sembolik bir rakam karşılığında bir bütün olarak ve ölümünden sonraki son arzularına uygun şekilde dağıtılması talimatını vererek güvendiği bir kişiye mancipatio ile devretmesi ve devralanın da (familia emptor) nuncupatio ${ }^{77}$ denen bir işlemle bu malvarlığını mirasbırakanın son arzularına uygun şekilde dağıtacağını taahhüt ederek devralması suretiyle meydana gelen bir işlemdir ${ }^{78}$. Vasiyet eden, fiil ehliyetine sahip beş Roma vatandaşı ile bir libripens (terazi tutan) önünde durur ve "bu malları bu tahta ve mum üzerinde yazılı olduğu şekilde sana veriyorum/bırakıyorum/vasiyet ediyorum" der ve tanıklara dönerek "Quirites! siz de buna tanık olunuz" diye bağırır ve tahta levhaları alıcı konumunda olan familiae emptor'a teslim ederdi. Alıcı da "malvarlı̆̆ının senin emrin ve benim nezaretim altında olduğunu beyan ediyor, kanuna uygun şekilde vasiyetlerini yerine getirmek için onları bu külçe ile satın alıyorum" diyerek cevap verir ve bakır külçe ile teraziye vurarak, bakırı da satış bedeliymiş gibi devredene teslim ederdi ${ }^{79}$. Bu merasime ilaveten bazen, bu beş Roma vatandaşı ile libripens ve familiae emptor'un mumlu tahta parçaları

75 Çeviri için bkz. Küçükgüngör E., Testamentum, s. 126.

76 Çeviri için bkz. Küçükgüngör E., Testamentum, s. 128.

77 Nuncupatio; per aes et libram, mancipatio, nexum gibi tasarruf işlemlerinde malı devreden ve devralanın söylemiş oldukları kalıplaşmış sözlerdir (Umur Z., Lügat, s. 143).

78 Gai. Inst., 2. 102-103, ayrıca bkz. Koschaker P./Ayiter K., s. 262; Günal, N., s. 432.

79 Di Marzo S., s. 520. Familiae emptor'un devraldığı malların hangileri olduğu açıkça ve teker teker belirtmeye de lüzum görülmemiştir. Zira malların çoğunun taşınmaz olduğu ve dolayısıyla külçe ve terazi ile ölçülmesinin fiilen olanaksız olduğu bir devirde buna gerek duyulmamış olsa gerektir (Boissarie R., s. 43). 
üzerine mühürlerini koymaları da istenebilirdi ${ }^{80}$. Görüldüğü üzere testamentum per aes et libram vasiyetname, malvarlığını devreden mancipans, malvarlığını devralan familiae emptor ve terazi tutan libripens ile beş tanık huzurunda gerçekleştirilen bir işlemdir.

Testamentum per aes et libram’ın hukuki niteliği hukukçular arasında ihtilaflıdır. Bir tasarruf işlemi olduğuna kesin gözüyle bakılmakla birlikte nasıl bir tasarruf işlemi olduğu izaha muhtaçtır. Bu konuda akla gelen çeşitli olasılıklar arasında yüklemeli bağışlama, mirasçı atama, ölüm sonrası vekalet, vasiyeti yerine getirme görevlisi tayini gibi işlemler vardır. Testamentum per aes et libram'ın ilk şeklini mancipatio familiae olarak kabul eden Lévy-Bruhl'a göre, mancipatio familiae ilk ortaya çıkışında, tereke mallarının sağlar arası bir işlemle basit bir devrinden ibarettir ve bu nedenle tam anlamıyla bir vasiyetname olarak nitelendirilemez. Zira malvarlığını elde eden kişi başka, mirasbırakanın aile ilişsilerini devam ettirecek kişi başkadır, bu da familiae emptor'un teknik anlamda bir mirasçı olmadığına işaret eder. Sağlar arası bir işlem niteliğinde olması sebebiyle per aes et libram'ın bir vasiyetname olarak nitelendirilmesi maddeten de imkansızdır. Bu işlem ancak bir mirasçı atama tasarrufunu içerdiği andan itibaren gerçek bir vasiyetnameye dönüşmüş olmalıdır ${ }^{81}$. Cuq, testamentum per aes et libram'ı calatis comitiis ile mancipatio familiae'ın bir karması olarak görmektedir. Bu işlemin mirasçı atamasını içermek zorunda olduğu, başka deyişle, malları devralan kişi mirasçı statüsünde kabul edildiği için calatis comitiis karakteri gösterir; malların devir ve temlik işlemleri ile intikalini öngördüğü için de mancipatio familiae karakteri gösterir ${ }^{82}$. Bu konuda Di Marzo ise, ilk zamanlarda mülkiyetin familiae emptor’a geçtiği ve fakat inanılana olan güvenin yitirilmeye başlandığı dönemlerden itibaren familiae emptor'un mülkiyeti kazanamayan basit bir tanık statüsüne indirgendiği fikrindedir ${ }^{83}$. Bu güvenin yitirilmesine bağlı olarak mirasbırakan, malvarlığını inanılana devretmek yerine doğrudan atadığı mirasçıya devretmeye başlamış ve böylece bu işlemin bünyesindeki mancipatio da tek taraflı bir işleme dönüşmüştür ${ }^{84}$.

Per aes et libram ya da mancipatio familiae testamentum'un hukuki niteliği konusunda bizim fikrimiz, bunun ilk ortaya çıktığı an itibariyle gerçekten de bir vasiyetname olarak nitelendirilemeyecek olduğudur. İlk zamanların katı şekilci anlayışı hesaba katıldığında bu görüşümüz haklılaşır. Vasiyetnamenin olağan şekli testamentum calatis comitiis olup bunun dışındaki bir şekil geçerli değildir. Mancipatio familiae ve onun dönüşmüş hali olan testamentum per aes et libram, yaşlı ve hasta olan kişileri vasiyetname yapma olanağına kavuşturmak maksadıyla ortaya çıkmış istisnai bir işlemdir. Mirasbırakanın malvarlığının familiae emptor'a devrinin henüz sağlıktayken yapılması bu işlemin bir ölüme bağlı tasarruf olarak düşünülmediğini ortaya koymaktadır. Ayrıca, mirasbırakanın malvarlığını devrettiği familiae emptor mirasçılardan biri olduğu vakit, familiae emptor'un bir vasiyeti yerine getirme görevlisi niteliğinde olduğunu söylemek de zorlaşır. Aynı sonuca familiae emptor'un

80 Gai. Inst., 2. 103; ayrıca bkz. Umur Z., Ders Notları, s. 511; Di Marzo S., s. 520; Boissarie R., s. 43; Küçükgüngör E., Testamentum, s. 127.

81 Lévy-Bruhl H., s. 637 vd. ile s. 662.

82 Cuq E., s. 685.

83 Di Marzo S., s. 519-520; aynı yönde Umur Z., Ders Notları, s. 511.

84 Di Marzo S., s. 519-520. 
mirasçılar arasından seçilmediği durum için de varılmalıdır zira bu durumda da familiae emptor'un sıradan bir alıcıdan farkı yoktur ve bu manada bir mirasçı olarak nitelendirilemez ${ }^{85}$.

Bize göre bu işlem ölüm sonrası vekaletin özel bir uygulamasıdır (mandatum post mortem). Mirasbırakan, ölüm sonrası isteklerini yerine getirmesi için familiae emptor’a tüm malvarlığını henüz sağlı̆̆ındayken devretmekte ve fakat familiae emptor'un borçları mirasbırakanın ölümünden sonra hüküm doğurmaktadır. Katı şekil şartlarından arınmış olması nedeniyle sorunsuz ve zahmetsiz yapılabilen bu işlem, bu özellikleriyle zamanla uygulamada daha yaygın kullanılması ve familiae emptor'un mirasçılar arasından seçilmeye başlanmasıyla da malvarlığının devrine gerek kalmayıp sadece tanıklar huzurunda yapılan bir beyanın yeterli görülmesiyle, sağlar arası olmaktan çıkıp ölüme bağlı bir tasarruf niteliğini kazanmış olsa gerektir.

Hukuki niteliği tartışmalı olsa da per aes et libram'da familiae emptor'un mancipatio familiae’da görülenin aksine basit bir alıcıdan ibaret olmadığı kesindir. Familiae emptor, müteveffanın son arzularını yerine getirmek ve bunun için malvarlığını devralmak ve devraldığı bu malları müteveffanın son arzuları doğrultusunda dağıtmak durumunda olan bir kişidir; bu kişinin bu işleviyle mirasçıdan bir farkı yoktur ${ }^{86}$.

Testamentum per aes et libram’ın şeklî şartlarında zaman içinde değişmeler olsa da bu vasiyetnamenin yapılmasına tanıkların iştirak etme mecburiyetleri hiçbir zaman ortadan kalkmamıștır. Bununla birlikte herkesin tanıklığ 1 da kabul edilmeyerek vasiyet eden ile familiae emptor'un hakimiyeti altında bulunan kimselerin, muhtemelen bu vasiyetnameden hak iktisap edecek durumda olmaları ve bu nedenle işlemin geçerliliği noktasında kendi çıkarlarını korumaya meyledecek olmaları yüzünden, testamentum per aes et libram'ın yapılışına tanık olarak katılmaları yasaklanmıştır. Aynı durum familiae emptor'un paterfamilias' 1 için de geçerlidir ${ }^{87}$.

Testamentum per aes et libram'ın geçerli olması için, tanıkların vasiyet eden tarafından gösterilen tabulae üzerine mühürlerini koymaları ve mührün yanına da isimlerini yazmaları şarttı. Familiae emptor'un, libripens'in ve bunların dışında beş tanığın daha imzalarını derç etmeleri ile işlemin şeklî şartları tamamlanmış olurdu. Bu kişilerin mühür ve isim dercetmek suretiyle koyacakları imza şartı başlangıçta kurucu unsur iken zamanla sadece bir ispat şartına dönüşmüştür. Bu imzaların yer almadığ vasiyetnameler ise ancak vasiyet edenin iradesinin per aes et libram bir vasiyetname yapmak olduğu açıkça kanıtlandı̆̆ 1 takdirde geçerli sayılmıştır ${ }^{88}$.

Testamentum per aes et libram, mancipatio familiae'daki olumsuzlukları da ortadan kaldıran ve bu sebeple pratik ihtiyaçlara daha fazla cevap veren bir kurum olmuştur. Zira testamentum per aes et libram'daki familiae emptor sıradan bir alıcı olmayıp mirasçı yerine geçen (loco heredis) bir kişi olup bu durum malvarlığı üzerinde ölüm sonrası etki doğurmak üzere tasarrufta bulunan bir kimsenin

85 Mancipatio familiae’ın Roma toplumuna özgü bir kurum olmayıp çağdaşı olan başka toplumlarda da benzer kurumlara rastlandığı öne sürülmüştür, mesela Cermen hukukundaki treuhand böyledir (ayrıntı için bkz. Lambert E., s. 49 vd.).

86 Boissarie R., s. 61; Cuq E., s. 685.

87 Di Marzo S., s. 521.

88 D. 37. 11. 1. 2; Di Marzo, s. 521; ayrıca bkz. Küçükgüngör E., Testamentum, s. 137. 
iradesine daha uygundur. Yine mancipatio familiae'da devir işlemleri cüzi intikal kurallarına göre gerçekleşmekte iken burada malvarlığı bir kül olarak devredilir. Mancipatio familiae'da familiae emptor malları kendisine devreden kimsenin iradesine aykırı olarak hareket edecek olursa ona karşı ikame edilebilecek bir dava yoktur. Aynı şekilde tereke alacaklılarının da familiae emptor'a karşı bir dava hakları yoktur. Testamentum per aes et libram'da ise, familiae emptor, heredis loco sıfatını taşıdığından bu malvarlığını müteveffanın son arzularına uygun olarak dağıtacağına dair özel bir taahhütte bulunur ve bu taahhüdüne aykırı davranması halinde de bundan sorumlu tutulurdu. Yine mancipatio familiae'da bir kimse mallarını çocuklarına doğrudan devredemezdi çünkü birinin diğerinin hakimiyeti altında olduğu iki kişi arasında mancipatio geçersiz olurdu. Gerçekten de baba çocuğuna malvarlığını mancipatio ile devretmiş olsa dahi bu malvarlığı, aile evlatlarının hak ehliyetleri bulunmadığ 1 için, yine aile reisinin mülkiyetine dahil olacaktı. Oysaki testamentum per aes et libram'da familiae emptor malların mülkiyetini daimi olarak kazanan bir kişi değildir, bu malları ölenin son arzularına uygun şekilde dağıtmak taahhüdüyle devralmış bir kimsedir, bu nedenle, burada artık bu vasiyetname sadece ölenin irade açıklamasıyla kurulan tek taraflı bir nitelik gösterir ${ }^{89}$.

\section{Praetor'un Vasiyetname Şekilleri Üzerindeki Etkileri}

Eski Hukuk Devrinin calatis comitiis ile in procinctu vasiyetnamelerinin yerini alan ve Klasik Hukuk Devrinin sonlarına kadar hakimiyetini sürdüren testamentum per aes et libram'a zamanla praetor'un müdahalesi başlamıştır. Çünkü testamentum per aes et libram için aranan şekil şartları her ne kadar calatis comitiis vasiyetname ile kıyaslandığında daha basit olsa da, hayatın pratik ihtiyaçları karşısında yine de komplike ve zahmetlidir ${ }^{90}$. Per aes et libram vasiyetnameye ait merasimdeki bir özensizlik, mesela formüldeki bir hata ya da sarf edilen sözlerdeki bir yanlışlık, hatta terazideki bir dengesizlik dahi bu vasiyetnamenin geçersiz olmasını sonuçlayabiliyordu' ${ }^{91}$. Praetor bu sakıncayı giderebilmek için zamanla per aes et libram vasiyetnameye müdahale etmeye başlamıştır. Ancak bu müdahale bir kanun koyucu mahiyetinde olmayan ${ }^{92}$ praetor'un bu vasiyetnameye doğrudan bir geçerlik tanımasıyla olmamıştır. Praetor bu müdahaleyi bu vasiyetnameden hak sahibi olacak olan kişilere bir bonorum possessio ${ }^{93}$ (possessionem dabo) tevdi ederek terekenin zilyetliğini vermek suretiyle yapmıştır. İlk etapta terekenin zilyetliğini kazanan familiae emptor, bu yolla aynı zamanda zamanaşımı ile iktisap olanağı da kazanır ve zamanaşımı ile iktisap koşullarını sağlar sağlamaz da tam anlamiyla malik olurdu ${ }^{94}$.

89 Cuq E., s. 685; Di Marzo S., s. 519-520; Boissarie R., s. 60 vd.

90 Boissarie R., s. 80; Küçükgüngör E., Testamentum, s. 136-137.

91 Boissarie R., s. 76.

92 Ius. Inst., 1.2.7.

93 Bonorum possessio; ius civile’ye göre mirasçı olamayan ancak hakkaniyet gereği mirasçı olması gerektiği düşünülen kimselere praetorlar tarafından terekenin zilyetliğinin verilmesi ve bu suretle bu kimselerin mirasçının yararlandığ haklardan yararlandırılmasıdır. Bu kurum praetorlar tarafından Roma miras hukukuna getirilmiş önemli bir yenilik olarak görülmektedir (Günal, N., s. 430).

94 Di Marzo S., s. 517-518; Boissarie R., s. 78-79; Küçükgüngör E., Testamentum, s. 137-138. Zamanaşımı ile iktisap ihtimalinde elbette kanuni mirasçıların miras sebebiyle istihkak talepleri saklıydı (Boissarie R., s. 80). 
Terekenin zilyetliğini praetor'un müdahalesi sayesinde elde eden familiae emptor per aes et libram vasiyetname ile öngörülen yükümlülükleri üstlenmiş olacağı için tereke alacaklıları tarafından kendisine karşı açılacak utiles nitelikte davalara katlanmak zorundaydı. Buna karşılık kendisinin de tereke üzerindeki zilyetlikten doğan hakları mevcut olduğundan terekenin korunması için gerekli önlemleri alabilir ve o da tereke borçlularına karşı actiones utiles açabilirdi ${ }^{95}$.

Mancipatio muameleri eksik ya da yanlış olan yahut da geçerlik için aranan diğer şartlarından yoksun bulunan per aes et libram vasiyetnamenin praetor müdahalesiyle geçerli sayılması zamanla bu vasiyetnameyi basit bir yazılı vasiyetnameye dönüştürmüştür. Zira testamentum per aes et libram lehdarı kişilerin, bu vasiyetnamenin metni olan ve vasiyet eden ile libripens ve beş tanık tarafından imzalanması gereken tabulae’ını ibraz etmeleri yeterli görülmüştür, mancipatio ile malların devri şartı aranmamıştır. Hatta adı geçen kişilerin imzaları da kurucu unsur ya da sıhhat şartı değil, ispat şartı gibi kabul edilerek vasiyetnamenin varlığının kanıtlanması yeterli görülmüștür ${ }^{96}$. Bu durum testamentum per aes et libram vasiyetnameyi aynı zamanda sözlü bir vasiyetnameye de dönüştürmüştür, çünkü per aes et libram bir vasiyetnameden söz edebilmek için vasiyet edenin bu şekle uygun bir vasiyetname yapmak iradesinin bulunduğunu kanıtlamak gerek ve yeterdir ${ }^{97}$.

Testamentum per aes et libram vasiyetnameye praetor'un müdahalesi konusunda önemle belirtmek gerekir ki bu müdahale bu vasiyetname türünün aslî şekil ve özünü kaybetmesine kesin olarak neden olmuştur. Ancak bu müdahale sonrası ortaya çıkan vasiyetnamenin yeni bir vasiyetname şekli olarak kabul edilip "praetor vasiyetnamesi" olarak adlandırılması yersiz olur. Zira praetor bu yolla yeni bir vasiyetname türü yaratmış ve bunu ius civile’ye dahil etmiş demek değildir ${ }^{98}$. Gerçekten de, burada, sadece şekil şartları bakımından geçersiz olan bir ölüme bağlı tasarruf iradesinin yargılama makamı tarafından geçerli bir vasiyetnameye tahvili söz konusudur.

\section{Postklasik Hukuk Devrinde Vasiyetname Şekilleri}

Postklasik Hukuk Devre gelindiğinde ise, mancipatio’nun yürürlükten kalkmasına paralel olarak, vasiyetnameler sadece sözlü ya da yazılı şekilde yapılan bir işleme dönüşmüştür ve böylece bu devirde vasiyetnamenin sözlü ve yazılı olmak üzere iki türü ortaya çıkmıştır. "Testamentum per nuncupationem" adıyla bilinen sözlü vasiyetname, yedi tanık huzurunda hazır bulunan mirasbırakanın son arzularını açıkladığı ve tanıkların da bu beyanı duyduklarına dair onay verdikleri işlemdir. Tüm safhalarının arka arkaya tamamlanması gereken ve bu nedenle uno actus bir işlem olan testamentum per nuncupationem bize göre bugünkü resmi vasiyetnameye benzemektedir ${ }^{99}$. Testamentum per scripturam adı altındaki yazılı vasiyetname ise, mirasbırakanın yine yedi tanık huzurunda ancak bu defa iradesini yazılı olarak açıklayıp kapalı bir şekilde, mesela iple bağlayarak ya da kapalı bir

95 Boissarie R., s. 80.

96 Ius. Inst., 2. 10.2.

97 Boissarie R., s. 80.

98 Boissarie R., s. 80

99 Ayrıca bkz. Di Marzo S., s. 521. 
kutu içinde, metnin kendisine ait olduğunu beyan ederek sunduğu, tanıkların da bu belgenin altına koydukları imza ile tamamladıkları bir usule sahiptir ${ }^{100}$.

Per aes et libram vasiyetnamenin etkisiz kalıp yürürlükten kalkmasıyla familiae emptor ve libripens denen kişilere de ihtiyaç kalmadı. Bu sebeple vasiyet edenin ölüm sonrası hüküm ifade etmesini istediği iradesini beş tanık huzurunda açıklaması ve bu tanıklar tarafından mühür ve imzaların konması yeterliydi ${ }^{101}$. Per aes et libram'ın yerini almış olan bu yeni vasiyetname şekli “ius civile ve ius praetorium mucibince vasiyetname" adiyla bilinmektedir ${ }^{102}$. Iustinianus ise bu vasiyetnameye testamentum tripartitum adını vermiştir ${ }^{103}$. Bunun nedeni bu vasiyetname şeklinin oluşmasında hem ius civile, hem praetor hukuku, hem de imparatorların müdahalesinin söz konusu olmasındandır yani bu vasiyetnamenin her üç kaynaktan da beslendiğini ifade içindir ${ }^{104}$. Nitekim bu vasiyetname, özünde per aes et libram olduğu için asıl olarak ius civile’den doğmakta, mühür ve imza şartı praetor hukukundan gelmekte, sonrasında aranmaya başlanan salt vasiyet eden ile beş tanık tarafından imza şartı ise imparator emirnamelerinden kaynaklanmaktadır ${ }^{105}$.

Posklasik Hukuktan itibaren Roma Hukukunda yazılı vasiyetname şeklinin hakim olduğunu söylemek yanlış olmaz ${ }^{106}$. Yazılı vasiyetname şeklinde vasiyetname metninin vasiyet eden tarafindan yazılması esas olmakla birlikte vasiyet edenin iradesine uygun doldurulması kaydiyla bir başka kimse tarafından kaleme alınması da mümkündür ${ }^{107}$. Yazılan metin açık ya da kapalı olarak tanıklara sunulur, vasiyet eden tanıklar huzurunda bu vasiyetnamenin kendisine ait olduğunu beyan eder, imzalar ve nihayetinde tanıklar da aynı anda ve arka arkaya (uno actus) mühürleyip imza ederlerdi. Vasiyet edenin okuma yazma bilmeme problemi ise işleme sekizinci bir tanığın dahil edilerek bu kişinin vasiyet eden adına vasiyetname metnini imza etmesinin kabulüyle çözümlenmiştir ${ }^{108}$.

\section{E. Iustinianus Hukukunda Vasiyetname Şekilleri}

Iustinianus hukukuna gelindiğinde tüm bu vasiyetname şekilleri bir araya getirilmiştir. Yazılı şekil için aranan karışı usuller basitleştirilerek vasiyetnameyi düzenleyen kişinin sadece el yazısı yeterli görülmüştür. Vasiyetname iradesinin şehir noteri (tabularius) önünde beyan edilerek

100 Bunların yanında bu dönemde vasiyetnameler için başka şekillerin öngörüldüğü de gözlenir; mesela şehir memurları önünde yapilan testamentum apud actum conditum, imparatora teslim edilmek üzere yapilan testamentum principi oblatum bu konuda birkaç örnektir (Di Marzo S., s. 523).

101 Di Marzo S., s. 523.

102 Di Marzo S., s. 523.

103 Ius. Inst., 2. 10. 3.

104 Accarias C., s. 852.

105 Ius. Inst., 2. 10. 3, ayrıca bkz. Di Marzo S., s. 523.

106 Küçükgüngör E., Testamentum, s. 144-145.

107 C. 6. 23. 21 pr.; ayrıca bkz. Küçükgüngör E., Testamentum, s. 144; Di Marzo S., s. 522. Vasiyetnameyi kaleme alan kişi kendi lehine bir hüküm koydurmuş olursa bu hüküm Senatusconsultum Libonianum (MS 16) gereğince batıldır (Di Marzo S. , s. 522 dn. 26).

108 Küçükgüngör E., Testamentum, s. 145. 
kaleme alınmasıyla tespit edildiği bugünkü resmi vasiyetnameye benzeyen bir uygulama da yine bu dönemde yerleşmiştir. Okuma yazma bilmeyenlerin beyanlarını sözlü açılklamak ve okuma yazma bilen bir tanığa imzalatmak suretiyle vasiyetname yapabilecekleri kabul edilerek okuma yazma bilmeyenler için de vasiyetname yapma imkanı getirilmiştir. Eski Hukuk devrinden beri var olan asker vasiyetnamelerinin de yine bu dönem itibariyle de korunduğu bilinmektedir ${ }^{109}$.

Iustinianus Hukukunda getirilen tüm bu yenilikleri dikkate aldığımızda, bu dönemde üç ayrı vasiyetname şeklinin kabul edilmiş olduğunu söylemek yanlış olmaz. Bunlar, yazılı vasiyetname, sözlü vasiyetname ve resmi vasiyetnamedir ${ }^{110}$. Yazılı vasiyetnameye ilişkin düzenlemeleri Ius. Inst. 2. 10. 12 'den öğreniyoruz.

Ius. Inst., 2. 10. 12

Vasiyetnamenin tahta parçaları, kağıt, deri veya herhangi bir madde üzerine yazılmış olmasının bir önemi yoktur.

Bu metinde vasiyetname metninin üzerine yazıldığı materyalin bir öneminin olmadığı belirtilmek suretiyle yazılı vasiyetnameden söz edilmektedir. Gerçekten de vasiyetname metni tahta levha, deri, kağıt gibi herhangi bir materyal üzerine yazılabilir. Metinde dikkati çeken husus ise, vasiyet eden ya da tanıklar tarafından imza edilmesi şartına hiç değinilmemiş olmasıdır. Ancak unutmamak gerekir ki yukarıda da temas ettiğimiz üzere per aes et libram vasiyetnamenin şekli basitleştirilerek sadece vasiyet eden ve tanıkların imzasını içeren bir vasiyetname şekline dönüşmüş olduğu için tanıkların imzası şarını açıkça anmaya gerek kalmamaktadır. Başka ifadeyle, Iustinianus'tan daha önce zaten bir yazılı vasiyetname mevcuttu ve Iusitinianus bu vasiyetnamenin şekil şartlarını basitleştirerek yine aynısını yürürlüğe koymuştu.

Iustinianus, yazılı vasiyetname için önceden aranan vasiyet edenin imzası zorunluluğunu vasiyet edenin kendisinin kaleme aldığı vasiyetnameler için kaldırmıştır. Buna göre vasiyet eden tarafından kaleme alınmış vasiyetnameler, sadece tanıklar tarafından imzalanarak; vasiyet eden tarafından değil başkası tarafından kaleme alınan vasiyetnameler ise, hem vasiyet eden hem tanıklar tarafından imzalanarak geçerli olabiliyordu ${ }^{111}$.

Pratik ihtiyaçlara göre yazılı vasiyetnamenin değişik şekillerine de rastlanmaktadır. Köylerde ikamet eden ve okuma yazma bilmeyenler için beş tanık huzurunda iradelerini açıklamaları ve bu iradenin kaleme alınarak tanıklar tarafından imzalanması suretiyle bu kişilerin de vasiyetname yapabilecekleri kabul edildi. ${ }^{112}$

109 Di Marzo S., s. 524-525; Küçükgüngör E., Testamentum, s. 144 vd.

110 Ius. Inst., 2. 10. 4; C. 6. 23. 21. 4; C. 6. 23. 19.

111 Bu hususu C. Iust. 6. 23. 28'den anliyoruz: "Eğer bir kimse bütün vasiyetnameyi veya codicillum’u kendi eliyle yazmışsa ve bunu vasiyetnamede açıķ̧a belirtmişse, bütünüyle elle yazılmasının yeterli olacağı kabul edilir ve vasiyet edenin ve onun yerine bir başkasının vasiyetnameyi imzalaması gerekmez", (Çeviri için bkz. Küçükgüngör E., Testamentum, s. 146).

112 C. 6. 23. 19, aynı yönde bkz. C. Ius. 6. 23. 31. 
Sözlü vasiyetnameye ise Ius. Inst. 2. 10. 14'de atıf yapılmaktadır:

Ius. Inst., 2. 10. 14

Bütün bu kaideler yazılı olarak tanzim edilen vasiyetnameler içindir. Şayet bir kimse, yazılı olmaksızın, yedi şahit çağırıp onların önünde iradesini beyan ederek ius civile mucibince vasiyette bulunmak isterse bu da ius civile'ye uygun ve emirnamelerimiz tarafından teyit edilmiş tam ve muteber bir vasiyetname teşkil eder.

Yine C. Ius. 6. 23. 21. 4'de de per nuncupationem yani sözlü vasiyetnamenin ne zaman geçerli olacağından bahsedilmektedir:

C. Ius. 6. 23. 21.4

Per nuncupationem quoque, hoc est sine scriptura, testamenta non alias valere sancimus, nisi septem testes, ut supra dictum est, simul uno eodemque tempore collecti testatoris voluntatem ut testamentum sine scriptura facientis

C. Ius. 6. 23. 21.4

Sözlü yani yazılı olmayan vasiyetnamenin, yukarıda belirtildiği gibi, tek ve aynı anda yedi tanığın çağrılmaması ve vasiyet edenin yazılı olmayan bir vasiyetname yapma yönündeki iradesini duymamaları durumunda, geçerli olmayacağına hükmederiz ${ }^{113}$.

Bu metne göre sözlü vasiyetname yedi tanık huzurunda ve vasiyet edenin sözlü vasiyetname yapma yönündeki iradesinin varlığı ve bu iradesini yedi tanık huzurunda açıkça beyan etmesi suretiyle geçerli olabilecektir.

Vasiyet edenin son arzularını şehir memurları ya da yargılama makamı önünde yaptığı bir açıklama ile yahut da imparatora bildirmek suretiyle düzenleyebilmesi de mümkün kılınmıştır. Testamentum apud acta conditum ${ }^{114}$ ve testamentum principi oblatum isimleriyle anilan ${ }^{115}$ bu vasiyetname şekilleri ${ }^{116}$, bize göre, günümüz resmi vasiyetnamesine benzemektedir.

\section{Sonuç}

$\mathrm{Bu}$ çalışmada ulaştığımız tespitlerden ilki, Romalıların vasiyetname işlemini daima şekle bağlı bir hukuki işlem olarak kabul ettikleri ve vasiyetname için özel şekiller tayin ettikleridir. Roma Hukukunun bilinen en eski vasiyetname şekilleri; barış zamanlarında cari olan olağan vasiyetname

113 Çeviri için bkz. Küçükgüngör E., Testamentum, s. 147.

114 Bu konuda bkz. Günal N., s. 434.

115 Di Marzo S., s. 523; Küçükgüngör E., s. 148.

116 Bu vasiyetnamelerin şekilleri hakkında bkz. Sütken E., Roma Hukuku’nda Şekil, YayımlanmamışDoktora Tezi, Anadolu Üniversitesi SosyalBilimler Enstitüsü, Eskişehir, 2010. 
türü testamentum calatis comitiis ve diğeri de, savaş zamanlarında yapılabilen ve bu nedenle istisnai nitelik taşıyan olağandışı vasiyetname türü testamentum in procinctu'dur. Olağan vasiyetname şekli olan testamentum calatis comitiis, 24 mart ve 24 mayıs olmak üzere yılda iki defa ve rahiplerin katılımı ile toplanan halk meclisleri önünde hazır bulunan vasiyet edenin, ölümünden sonra yerine geçecek kişinin kim olacağına dair iradesini açıklaması ile başlayıp rahipler ile halk meclisinin bu iradeyi onaylamasının ardından tamamlanan bir işlemdir. Testamentum calatis comitiis'in merasimleri bakımından dikkati çeken, bu vasiyetnamenin kalabalık bir halk kitlesi önünde kuruluyor olmasıdır. $\mathrm{Bu}$ da bize Romalılar tarafından ilk zamanlarda vasiyetname işleminin salt kişiyi ilgilendiren bir tasarruf olarak görülmeyip kamusal bir tasarruf olarak kabul edildiğini göstermektedir. Başka deyişle Romalılara göre ilk zamanlarda vasiyetname bir özel hukuk işlemi değil kamu hukuku işlemidir. Her iki vasiyetname şeklinin gerek merasime bağlı oluşu, gerek yıl boyu ancak iki defa yapılabiliyor olması, zamanla testamentum per aes et libram adıla bilinen ve pratik ihtiyaçlara daha iyi cevap veren yeni bir vasiyetname tipini ortaya çıkarmıştır. Bu vasiyetname türü vasiyet edenin malvarlığını sağlar arası bir işlemle güvenilir bir kişiye devrederek ona kendi ölümünden sonra bu malvarlığının son arzularına uygun olarak dağıtılmasını yüklemesi ile meydana gelen bir işlemdir. Bu nedenle ölüme bağlı tasarruftan çok sağlar arası bir işlem niteliği göstermektedir. Ancak zamanla bu işleme ölüme bağlı bir tasarruf niteliği atfedilmiştir. Klasik hukukta hakim olan testamentum per aes et libram'in ardından praetor ve imparatorların müdahaleleri ile yeni vasiyetname türleri ortaya çıkmıştır.

Iustinianus Hukukuna gelindiğinde eski dönemlerin karmaşık şekil ve kalıpları terk edilerek yazılı, sözlü ve resmi vasiyetname olarak üç ayrı vasiyetname şeklinin kabul edildiği gözlemlenir. Buna bağlı olarak çalışmamızda ulaştığımız son bir tespit ise, Roma Hukukunda başlangıçta karmaşık surette başlayan vasiyetname şekillerinin giderek basitleştirildiği ve vasiyetnamenin bağlanacağı şekil şartlarının tespitinde artık pratik ihtiyaçlara daha fazla önem atfedilerek düzenlemeler yapıldığıdır.

\section{KAYNAKLAR}

Accarias C.,Précis De Droit Romain, Tome I, 4. édition, Librairie Cotillon, 1886.

Appleton Cf.,Le Testament Romain, La Méthode Du Droit Comparé Et L’Authénticité Des XII Tables, 1903.

Berki Ş.,Roma Hukuku, Ankara, Ankara Üniversitesi Hukuk Fakültesi, 1949.

Boissarie R.,Des Formes Du Testament Romain, Paris, L. Larose Et Forcel, 1888.

Cuq E.,Manuel Des Institutionis Juridiques Des Romains, 2. éd., RevueEt Complétée, Paris, Librairie Plon/ Librairie Générale, 1928.

Di Marzo, S.,Roma Hukuku, Beşinci Tab’ından Çev. Ziya Umur, 2. Baskı,İstanbul, İstanbul Üniversitesi Yayınları, 1959.

Günal, N., "Roma Miras Hukuku’na Genel Bir Bakış ve Vasiyet Yolu İleMiras”, Ankara Üniversitesi Hukuk Fakültesi Dergisi, C. 44, S.1, 1995, s. 425-442.

Iustinianus

Institutiones, Türkçe metin: Ziya Umur, İstanbul, 1984.

İmre Z. / Erman H.,Miras Hukuku, Yasal Mirasçllık-Ölüme Bağlı Tasarruflar- Mirasın ～Geçmesi-Mirasın Taksimi, Gözden Geçirilmiş 14.basım, İstanbul, Der Yayınları, 2018.

İpek N., XII Levha Kanunu", Argumentum, Y1l: 3, Sayı: 34

İpek N., “Roma Hukukunda Hısımlık”, MÜHF-HAD, C. 21, S. 1, s. 167-203. 
Karagöz H., “Roma Hukukunda Mandatum Post Mortem (Ölümden SonraVekalet)”, Prof. Dr. Nihal Uluocak’a Armağan, İstanbul, 1999,s. 165- 178.

Kayak S.,Roma Hukukunda İkame (Substitutio) ve Türk HukukuÜzerindeki Etkisi, İstanbul, Filiz Kitabevi, 2019.

Koca Ö.,Roma Hukuku’nda ve Türk Hukuku’nda Ölüme BağlıTasarruflar, Ankara, Yetkin Yayınları, 2018.

Kocayusufpaşaoğlu N.,Miras Hukuku, Hiç Değiştirilmemiş 3. Bası, İstanbul, FilizKitabevi, 1987.

Koschaker P./ Ayiter K.,Modern Özel Hukuka Giriş Olarak Roma Özel Hukukunun Ana Hatları, İzmir, Dokuz Eylül Üniversitesi Hukuk Fakültesi Döner Sermaye İşletmesi Yayınları, 1993.

Küçükgüngör E., "Roma ve Türk Hukukunda Muayyen Mal Vasiyeti”, AnkaraÜniversitesi Hukuk Fakültesi Dergisi, C. 45, S. 1, 1996, s. 505-531.

Küçükgüngör E.,Roma Hukukunda Vasiyet (Testamentum), Ankara, Yetkin Y Yayınları, ２007， (Kısaltma: Testamentum)

Lambert E.,La Tradition Romaine Sur La Succession Des Formes DuTestament Devant L'Histoire Comparative, Paris, V. Giard \& E.Brière Librairies Editions, 1901.

Lambert J. N., “La Très Ancienne Succession Romaine Interprétée D’Après Le Droit Comparé”, RHD, 4. sèrie vol. 31, 1954.

Lepointe G.,Droit Romain Et Ancien Droit Français, Régimes Matrimoniaux, Libéralités, Successions, Paris, Editions Montchrestien, 1958, s. 15 N. 23.

Lepointe M.,Cours de Droit Romain, rédigé d’apres les Notes et avec l'Autorisation, Licence 1 année, Paris, 1948-1949.

Lévy-Bruhl H., "La Fonction Du Très Ancien Testament Romain”, NRHD, vol. 45, 1921, s. 634-669.

Monier R.,Manuel Elémentaire De Droit Romain, Tome I, IntroductionHistorique, Les Sources - La Procédure - Les Personnes - LesDroit Réels-Les Successions, 6. éd., Editions DomatMontchrestien, 1947.

Sandalcı S.,On İki Levha Yasaları, Yayımlanmamış Yüksek Lisans Tezi,İstanbul, İstanbul Üniversitesi Edebiyat Fakültesi, 1993.

Schmidlin B./ Augusto Cannata C., Droit Privé Romain, II, Obligations-Successions- $\quad P$ r o c é d u $r$ e, Lausanne, CJR, 1987.

Somer, P. "Dar anlamda Aile Hukukunun Esasları”, Maltepe ÜniversitesiHukuk Fakültesi Dergisi, C.1 S.2, 2002, s.155-180.

Söğütlü Ö.,Roma Özel Hukuku, Ankara, Seçkin Yayınevi, 2020.

Söğütlü Erişgin Ö.,Roma Kamu Hukukuna Giriş, Ankara, Seçkin, 2017.

Sütken E.,Roma Hukuku’nda Şekil, Yayımlanmamış Doktora Tezi,Anadolu Üniversitesi SosyalBilimler Enstitüsü, Eskişehir, 2010.

Tahiroğlu B.,"Quelques Ressemblances et Différences entre Le Droit Romainet Le Droit Moderne Turc Dans Les Droit Des Successions”Hukuk Araştırmaları Dergisi, C. 3, 1988, s. 5-23.

Türkoğlu, G. H., "Roma Cumhuriyet ve İlk İmparatorluk Dönemlerinin İdariYapısı”, Dokuz Eylül Üniversitesi Hukuk Fakültesi Dergisi, C.11, S. 2, 2009, s. 251-289.

Umur Z.,Roma Hukuku Ders Notları, Tipkı 3. Basım, İstanbul, Beta Yayıncılık, 2010 (Kısaltma: Ders Notları)

Umur Z.,Roma Hukuku Lügatı, İstanbul, İstanbul Üniversitesi Yayınları, 1983 (kısaltma: Lügat)

Umur, Z.Roma Miras Hukukunun Ana Hatları, İUHHFM, C. XXXI, Sayı: 1-4'den ayrı bası, İstanbul, İstanbul Üniversitesi Yayınları, 1966. 